\title{
Relationship among soil management, organic matter content and root development along the explorable soil profile in the vineyard
}

\author{
Alberto Vercesi ${ }^{1}$, Matteo Gatti ${ }^{1}$, Claudia Meisina ${ }^{2}$, Massimiliano Bordoni ${ }^{2}$, Michael Maerker ${ }^{2}$, Cristina \\ Ganimede ${ }^{1}$,Maria Cristina Reguzzi ${ }^{1}$, Emanuele Mazzoni ${ }^{1}$, and Stefano Poni ${ }^{2}$ \\ ${ }^{1}$ DI.PRO.VE.S. Department of Sustainable Crop Production, Università Cattolica del Sacro Cuore, Via Emilia Parmense 84, \\ 29122 Piacenza (PC) Italy \\ ${ }^{2}$ Dipartimento di Scienze della terra e dell'ambiente, Università di Pavia. Italy
}

\begin{abstract}
In the most ancient wine area of the Controlled Denomination of Origin (DOC) "Oltrepò Pavese" in North-West Italy, foothills of the Apennine mountains, the soils of 14 representative vineyards managed for about 10 years with tillage $(\mathrm{T})$ or natural grass-cover $(\mathrm{G})$ or the alternation of the two methods between the rows (GT), were compared for their contents of organic matter, main soil parameters and extent of root development, in the first meter of depth. The soils are fine textured, sometimes calcareous, with low levels of organic matter. G and GT soil treatments showed higher organic matter content (on average $1.4 \%$ ) than $\mathrm{T}(0.88 \%)$. Better root development (number and area) was observed in G and GT, in comparison with $\mathrm{T}$; the number and size of roots showed a positive correlation with the soil organic matter.
\end{abstract}

\section{Introduction}

The sustainability of viticulture is also based also on maintenance over time of the chemical and physical fertility of the soil. Under this point of view, organic matter, mineral elements and water availability in the soil play a fundamental role $[1,2]$. Good root development is also crucial to improve the sustainability of the vineyard, especially when established on hilly areas [3]. Soil management is known to strongly modify the soil physical and chemical characteristics of the vineyard and to affect vine roots development $[4,5,6]$; soil management practices leading to even small increases in soil organic matter can be worthwhile from the viewpoint of soil physical properties, while even small decreases resulting from soil management may cause greater negative effects [7].

The effects of the different cultural techniques on the balance of organic matter and root development change, according to different agroecosystems (scion and rootstocks genotype, type and depth of soil, climate and productivity required) and, for these reasons, it is important to improve the studies of the relationships between vine growth, soil management and organic matter content.

The zone under study in the present research is Oltrepò Pavese (Fig. 1), boasting about 13.000 ha of vineyards, where Croatina (ab. 3,900 ha), Pinot nero (ab. 2,500 ha) and Riesling italico (ab. 1,800 ha) are the most cultivated varieties for red and white wine production, respectively (ISTAT 2010, last agriculture census). For wine production, the area is among the top ten in Italy. Under the objective of studying this ancient viticulture, the soil organic matter content, and the development of grapevine roots in relation to some different management practices, this research was carried out within the project "Oltrepò bio-diverso ATTIV-AREE" (CARIPLO Foundation).

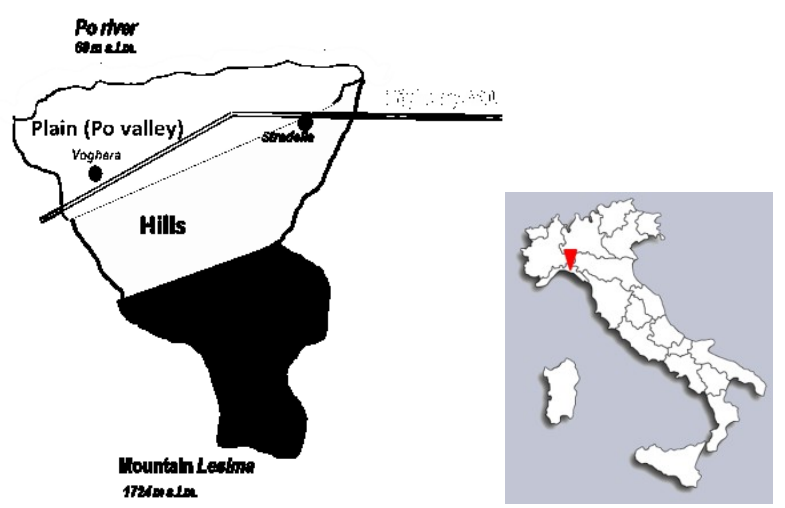

Fig. 1. The Oltrepò Pavese on the north-western Apennines, facing to the Po Valley (Stradella town: Latitude $45^{\circ} 04^{\prime} \mathrm{N}$, Longitude $9^{\circ} 18^{\prime} \mathrm{E}$ with about $720 \mathrm{~mm}$ of annual rainfall) [8].

\section{Material and methods}

Within the Oltrepò Pavese district, seven representative sites of local viticulture were taken into 
consideration from 2015 to 2017, identifying 14 vineyards in which, for at least 10 years, management of the soil was developed with: tillage $(\mathrm{T})$, or natural grass cover $(\mathrm{G})$ or the alternation of these two methods between the rows (GT) (Tab. 1).

Table 1. Sample vineyards selected, with the type of soil management used $(\mathrm{T}=$ total tillage, $\mathrm{G}=$ natural Grass, $\mathrm{GT}=$ alternation of the two methods between inter-rows), the location $(\mathrm{P} .=$ Pavese $)$ and the altitude (meters above sea level). The geological substrate were: CP and SD marls (Marne di $S$. Agata fossili), SMV alternation of sandstone and marls (Formazione Val Luretta), MP cc, ct silty and calcareous marls (Formazione di Contignaco), and MPcg calcareous marls (Marne di Monte Piano).

\begin{tabular}{|c|c|c|c|}
\hline \multicolumn{2}{|c|}{$\begin{array}{l}\text { Label and soil } \\
\text { management }\end{array}$} & Places & $\begin{array}{l}\text { Alt. } \\
\text { (m) }\end{array}$ \\
\hline $\mathrm{CP}$ ro & $\mathrm{T}$ & Canneto P. - roncole & 170 \\
\hline $\mathrm{CP} \mathrm{cb}$ & G & Canneto P. - casa bazzini & 178 \\
\hline SD br & G & S. Damiano - braccio & 156 \\
\hline $\begin{array}{r}\text { SMV } \operatorname{cn} 1 \\
\text { cn2 } \\
\text { cn3 } \\
\text { cn4 } \\
\text { cn5 }\end{array}$ & $\begin{array}{l}\text { T } \\
\text { G } \\
\text { GT } \\
\text { GT } \\
\text { GT }\end{array}$ & $\begin{array}{l}\text { S. Maria Versa - case } \\
\text { nuove }\end{array}$ & 270 \\
\hline $\begin{array}{ll}\text { MP } & \mathrm{cc} 1 \\
& \mathrm{cc} 2\end{array}$ & $\begin{array}{l}\mathrm{G} \\
\mathrm{G}\end{array}$ & Montalto P. - casa cuneo & 330 \\
\hline $\begin{array}{ll}\text { MP } & \text { ct1 } \\
& \text { ct2 } \\
\end{array}$ & $\begin{array}{l}\mathrm{T} \\
\mathrm{T} \\
\end{array}$ & Montalto P. - casa tacconi & 320 \\
\hline $\begin{array}{ll}\text { MP } & \text { cg1 } \\
& \text { cg2 } \\
\end{array}$ & $\begin{array}{l}\mathrm{G} \\
\mathrm{G}\end{array}$ & Montalto P. - costa gallotti & 344 \\
\hline
\end{tabular}

All vineyards were grafted on the same rootstock (SO4) but different varieties were featured: Croatina (CPro, CPcb, SMVcn1), Pinot nero (SMVcn2, MPcc), Riesling italico (MPct, MPcg) and Merlot (SMVcn3, SMVcn4, SMVcn5). In each of these vineyards, a profile excavation was opened and, for each $10-30 \mathrm{~cm}$ soil layer down to the depth of about $100-120 \mathrm{~cm}$, soil samples were collected for the determination of texture (USDA method) as \% of gravel, sands, silt and clay; organic matter $\%, \mathrm{pH}, \mathrm{CEC}$ cation exchange capacity meq $/ 100 \mathrm{~g}$, potassium exchangeable $(\mathrm{K}, \mathrm{mg} / \mathrm{kg})$ and magnesium exchangeable and $(\mathrm{Mg}, \mathrm{mg} / \mathrm{kg})$, phosphorous (P, "Olsen") calcium exchangeable (Ca $\mathrm{mg} / \mathrm{kg}$ ). At the same time, the number of vine roots and their section were determined to produce an estimate of the vine root systems along the soil profile (total number of roots, number of roots with diameter $>2 \mathrm{~mm}$, area of roots) on the basis of the data collected with photographic methodology used in the slope geology [10]. Analysis of variance was used to study the soil variables measured and to evaluate the effects of geological formation, as well as depth and type of soil management on the soil chemical main compounds and on the parameters related to root evaluation. The Levene statistic (L) was applied to test the homogeneity of the variances and when $L$ reached significant levels $(p<0,05)$ and variances were judged to be not homogenous, the Brown-Forsyte (bf) statistic was applied to test data variability [11]. When the results of the test ( $F$ or bf) were significant, the differences among the means were verified with the Student-Newman-Keuls test (SNK, $\mathrm{p}<0,05)$.

\section{Results and discussion}

\subsection{Soils characteristics}

The soils of the examined vineyards belong to four different geological formations [9]: Marne di S. Agata Fossili (Msaf), Marne di Monte Piano (Mmp), Formazione di Contignaco (FC) and Val Luretta (VL); more (Mmp) or less (Msaf) calcareous marl and alternation of marl and sandstone (FC and VL). Results from soil analysis (Tab. 2 and 3) highlight several significant differences among the different geological formations for: texture, carbonate content, and cation nutrient richness (sand, clay, limestone total and active, $\mathrm{K}$ and $\mathrm{Mg}$ exchangeable and CEC); the parameters found which varied significantly along the depths of soil were: organic matter and $\mathrm{pH}$.

Tab. 2. Soil textures. Geological formations (Geo.); Depths of soil (D.) range in $\mathrm{cm}$; Soil management (M.) $\mathrm{T}=$ Tillage,

$\mathrm{G}=\mathrm{Green}$ natural cover, $\mathrm{GT}=$ alternating of green natural cover and tillage, between the inter-rows. $\mathrm{L}=$ Levene test; $\mathrm{F}=$ Fisher test; bf=Brown Forsythe test; ns = not significant; * and ** = significant per $\mathrm{p} \leq 0.05$ and $\mathrm{p} \leq 0.01$, respectively. Within each column, medium values with different letters are significantly different at SNK test $(\mathrm{p}<0.05)$.

\begin{tabular}{|c|c|c|c|c|}
\hline Var. & Gravel & Sand & Silt & Clay \\
\hline \multirow[t]{2}{*}{$\begin{aligned} & \text { Geo. } L \\
& F \\
& b f\end{aligned}$} & $\begin{array}{l}4,46^{*} \\
- \\
1,43 n s\end{array}$ & $\begin{array}{l}17,7 * * \\
- \\
8,62 * *\end{array}$ & $\begin{array}{l}1,54 n s \\
- \\
1,47 n s\end{array}$ & $\begin{array}{l}11,7 * * \\
- \\
3,11 n s\end{array}$ \\
\hline & $\%$ & $\%$ & $\%$ & $\%$ \\
\hline Msaf & $1.88 \mathrm{a}$ & $18.48 \mathrm{~b}$ & 50.24 & $29.40 \mathrm{a}$ \\
\hline Mmp & $4.87 \mathrm{c}$ & $18.51 \mathrm{~b}$ & 43.30 & $33.31 \mathrm{a}$ \\
\hline FC & $2.54 \mathrm{ab}$ & $5.79 \mathrm{a}$ & 46,57 & $45.10 \mathrm{~b}$ \\
\hline VL & $3.32 \mathrm{~b}$ & $5.18 \mathrm{a}$ & 40.98 & $50.53 b$ \\
\hline \multirow{4}{*}{$\begin{array}{ll}\text { D. } & L \\
& F \\
b f\end{array}$} & $0.31 n s$ & $1.39 n s$ & $0.45 n s$ & $0.56 n s$ \\
\hline & $0.01 \mathrm{~ns}$ & $0.16 \mathrm{~ns}$ & $0.60 \mathrm{~ns}$ & $1.47 n s$ \\
\hline & - & - & - & - \\
\hline & $\%$ & $\%$ & $\%$ & $\%$ \\
\hline 0-40 & 3.01 & 9.08 & 46.39 & 41.51 \\
\hline $41-80$ & 2.87 & 7.89 & 43.56 & 45.68 \\
\hline $81-120$ & 3.02 & 10.23 & 43.08 & 43.67 \\
\hline \multirow{4}{*}{$\begin{array}{ll}\text { M. } & L \\
& F \\
& b f\end{array}$} & $3.47 *$ & $2.57 n s$ & $4.04 *$ & $4.75^{*}$ \\
\hline & - & & & $5.07 * *$ \\
\hline & $0.20 n s$ & - & $2.37 n s$ & - \\
\hline & $\%$ & $\%$ & $\%$ & $\%$ \\
\hline $\mathbf{T}$ & 2.65 & 11.85 & 44.49 & $40.99 \mathrm{a}$ \\
\hline $\mathbf{G}$ & 3.31 & 9.67 & 47.46 & $39.55 \mathrm{a}$ \\
\hline GT & 2.77 & 5.35 & 41.25 & $51.64 \mathrm{~b}$ \\
\hline
\end{tabular}

Soil texture varied between the geological formations, but it was quite uniform along the first meter of soil depth.

In general, the soil texture (Tab. 2) shows higher values of silt (about, $41-50 \%$ ) and clay $(29-50 \%)$, associated with lower levels of sand $(5.3-16.0 \%)$ and, above all, of gravel $(1.6-4.9 \%)$. According to the significant texture differences observed (Tab. 2), it is 
therefore possible to identify two main types of soil, the first $(V L$ and $F C)$ with higher level of clay $(>45 \%)$ and a very low sand content $(<5 \%)$, and a second soil (Msaf and $M m p$ ) where the silt is equal or higher than clay and the sand $(\approx 18 \%)$. Therefore, the first soil (VL and FC) is a Clay-Silt-Sand and the second (marls) is a Silt-ClaySand. Each texture fraction did not change significantly according to soil depth or the type of soil management adopted.

Table 3. Soil general parameters. O.M. =organic matter; $\mathrm{C}=$ carbon; $\mathrm{N}=$ Nitrogen; Limes. $=$ Limestone; $\mathrm{T} .=$ total; A. $=$ active (see also the caption of Tab. 2).

\begin{tabular}{|c|c|c|c|c|c|}
\hline Var. & pH & O.M. & $\begin{array}{c}\text { Limes. } \\
\text { T. }\end{array}$ & $\begin{array}{c}\text { Limes. } \\
\text { A. }\end{array}$ & CEC \\
\hline \multirow{4}{*}{ Geo. $\begin{array}{r}L \\
F \\
b f\end{array}$} & $3.04 n s$ & $2.93 n s$ & $17.2 * *$ & $10 ., 7^{* *}$ & $4.68 * *$ \\
\hline & $2.68 n s$ & $3.87 *$ & & & \\
\hline & - & - & $22.3 * *$ & $22.2^{* *}$ & $31.1 * *$ \\
\hline & & $\%$ & $\%$ & $\%$ & $\mathrm{meq}^{1}$ \\
\hline \multirow{2}{*}{$\begin{array}{l}\text { Msaf } \\
\text { Mmp }\end{array}$} & 8.32 & 1.44 & $20.75 b$ & $10.04 \mathrm{ab}$ & $16.31 \mathrm{a}$ \\
\hline & 8.18 & 1.87 & $23.25 \mathrm{~b}$ & $11.25 \mathrm{~b}$ & $18.54 \mathrm{a}$ \\
\hline $\begin{array}{r}\text { Mimp } \\
\text { FC }\end{array}$ & 8.25 & 1.04 & $27.20 \mathrm{~b}$ & $13.18 \mathrm{~b}$ & $20.10 \mathrm{a}$ \\
\hline VL & 8.21 & 1.23 & $12.89 \mathrm{a}$ & $6.91 \mathrm{a}$ & $33.07 \mathrm{~b}$ \\
\hline \multirow{4}{*}{$\begin{array}{cc}\text { D. } & L \\
& F \\
& b f\end{array}$} & $0.11 n s$ & $2.2 \ln s$ & $4.97 * *$ & $0.22 n s$ & $0.93 \mathrm{~ns}$ \\
\hline & $9.22 * *$ & $10.3^{* *}$ & - & $3.77 *$ & $0.3 \ln s$ \\
\hline & . & - & $1.87 n s$ & - & - \\
\hline & & $\%$ & $\%$ & $\%$ & $\mathrm{meq}^{\mathrm{I}}$ \\
\hline $0-40$ & $8.11 \mathrm{a}$ & $1.75 b$ & 22.23 & $11.39 \mathrm{~b}$ & 22.62 \\
\hline $41-80$ & $8.30 \mathrm{~b}$ & $1.05 \mathrm{a}$ & 19.31 & $9.69 \mathrm{ab}$ & 25.75 \\
\hline $81-120$ & $8.36 \mathrm{~b}$ & $0.88 \mathrm{a}$ & 15.83 & $7.41 \mathrm{a}$ & 26.96 \\
\hline \multirow{4}{*}{$\begin{array}{ll}\text { M. } & L \\
& F \\
& b f\end{array}$} & $3.04 n s$ & $3.04 n s$ & $17.18^{* *}$ & $10.7 * *$ & $4.68^{* *}$ \\
\hline & $2.68 n s$ & $3.87^{*}$ & - & 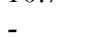 & - \\
\hline & - & - & $22.3^{* *}$ & $22.2 * *$ & $31.0 * *$ \\
\hline & & $\%$ & $\%$ & $\%$ & $\mathrm{meq}^{\mathrm{I}}$ \\
\hline $\mathbf{T}$ & 8.34 & $0.88 \mathrm{a}$ & 44.49 & 40.99 & $19.63 \mathrm{a}$ \\
\hline \multirow{2}{*}{$\begin{array}{r}\text { G } \\
\text { GT }\end{array}$} & 8.18 & $1.53 b$ & 46.23 & 41.41 & $21.62 \mathrm{a}$ \\
\hline & 8.23 & $1.26 \mathrm{ab}$ & 41.29 & 50.30 & $34.46 \mathrm{~b}$ \\
\hline
\end{tabular}

Regarding the main general chemical characteristics of the soil (Tab. 3), only limestone and CEC changed significantly among the different geological formations. Limestone is lower in $\mathrm{VL}$ and higher in FC, with about $13 \%$ and $27 \%$, respectively; the marls soils (Msaf and $\mathrm{Mmp}$ ) have intermediate calcareous values compared to the first two. The variations of O.M. and $\mathrm{pH}$ was not significant among different geological formations. With the depth of soil, O.M. decreases and $\mathrm{pH}$ increases. Limestone, $\mathrm{pH}, \mathrm{CEC}$ and O.M. were affected by the type of soil management used, with significantly higher $\mathrm{pH}$ and limestone in the case of Tillage, whilst the soils managed for years with green cover alternated with tillage showed a lower level of limestone. Regarding availability of mineral ions in soils (Tab. 4), the geological formations caused significant differences for Potassium, Magnesium and Calcium-, N and P contents did not change substantially according to the geology variation of the substrates. All the elements appeared to vary significantly with the depth of soil, with the exception of $\mathrm{Mg}$; in fact $\mathrm{N}, \mathrm{P}, \mathrm{K}$ and $\mathrm{Ca}$ decreased significantly with the depth of soil.

According to the texture observed, it is possible identify two main agronomic types of soil: Marls (Msaf and Mmp) and Clays (FC and VL) with a low variability in the first meter of depth; among the different types of soil management methods studied, the differences were mainly not significant, with the exception of N, O.M., $\mathrm{LsA} \%, \mathrm{MgO}$ and $\mathrm{CaO}$.

Table 4. Main mineral macronutrients. $\mathrm{N}=$ nitrogen, $\mathrm{K}=$ potassium, $\mathrm{Mg}=$ magnesium, exc. $=$ exchangeable (see also the caption of Tab. 2).

\begin{tabular}{|c|c|c|c|c|c|}
\hline Var. & $\mathbf{N}$ & $\mathrm{C} / \mathrm{N}$ & $\begin{array}{c}\mathrm{K} \\
\text { exc. }\end{array}$ & $\mathbf{P}$ & $\begin{array}{l}\text { Mg } \\
\text { exc. }\end{array}$ \\
\hline \multirow{4}{*}{$\begin{array}{cc}\text { Geo. } & L \\
& F \\
& b f\end{array}$} & $1.44 n s$ & $1.19 n s$ & $2.71 *$ & $3.61 *$ & $2.37 n s$ \\
\hline & $1.30 n s$ & $2.10 n s$ & $5.34 * *$ & $8.42 * *$ & $27.5 * *$ \\
\hline & - & - & $6.58 * *$ & $4.08 n s$ & 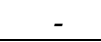 \\
\hline & $\%$ & & $\mathrm{mg} / \mathrm{kg}$ & $\mathrm{mg} / \mathrm{kg}$ & $\mathrm{mg} / \mathrm{kg}$ \\
\hline Msaf & 1.01 & 8.33 & $141 \mathrm{a}$ & 6.75 & $182 \mathrm{a}$ \\
\hline Mmp & 1.25 & 8.68 & $335 c$ & 23.24 & $160 \mathrm{a}$ \\
\hline FC & 0.79 & 7.79 & $192 \mathrm{ab}$ & 5.61 & $522 \mathrm{a}$ \\
\hline VL & 0.86 & 8.40 & $273 b c$ & 6.42 & $1196 b$ \\
\hline \multirow{4}{*}{$\begin{array}{l} \\
F \\
b f\end{array}$} & $0.44 n s$ & $3.13 n s$ & $1.59 n s$ & $7.85 * *$ & $0.21 n s$ \\
\hline & $11.0 * *$ & $1.21 n s$ & $3.56^{*}$ & - & $5.95 * *$ \\
\hline & - & - & - & $7.22 * *$ & - \\
\hline & $\%$ & & $\mathrm{mg} / \mathrm{kg}$ & $\mathrm{mg} / \mathrm{kg}$ & $\mathrm{mg} / \mathrm{kg}$ \\
\hline \multirow{2}{*}{$\begin{array}{r}0-40 \\
41-80\end{array}$} & $1.22 \mathrm{~b}$ & 8.24 & $285 b$ & $12.52 \mathrm{~b}$ & $444 a$ \\
\hline & $0.77 \mathrm{a}$ & 8.01 & $205 \mathrm{ab}$ & $5.46 \mathrm{a}$ & $765 \mathrm{ab}$ \\
\hline $81-120$ & $0.61 \mathrm{a}$ & 8.50 & $187 \mathrm{a}$ & $3.91 \mathrm{a}$ & $1049 \mathrm{~b}$ \\
\hline \multirow[t]{4}{*}{ M. } & $2.15 n s$ & $1.99 n s$ & $2.18 n s$ & $2.40 n s$ & $0.94 n s$ \\
\hline & $4.25 * *$ & $1.73 n s$ & $1.92 n s$ & $1.55 n s$ & $33.9 * *$ \\
\hline & - & - & - & - & - \\
\hline & $\%$ & & $\mathrm{mg} / \mathrm{kg}$ & $\mathrm{mg} / \mathrm{kg}$ & $\mathrm{mg} / \mathrm{kg}$ \\
\hline $\mathbf{T}$ & $0.65 \mathrm{a}$ & 8.08 & 196 & 5.08 & $517 \mathrm{a}$ \\
\hline G & $1.09 b$ & 8.09 & 220 & 10.05 & $405 a$ \\
\hline GT & $0.85 b$ & 8.60 & 280 & 6.92 & $1363 b$ \\
\hline
\end{tabular}

\subsection{Root development}

In general, the study showed roots exploring soils at a depth of about $1.0-1.2 \mathrm{~m}$, the limit reached without excessive effort by the excavator blade and that corresponded to the depth where the roots became sporadic. In two cases of vineyard managed with total tillage of the soil, the roots became sporadic starting from $80 \mathrm{~cm}$. The majority of the roots (by number) were confined in the first $60 \mathrm{~cm}$ of depth (on average $68,4 \%$ of the roots), at about $80 \mathrm{~cm}$ the limit of $90,0 \%$ of the total roots was exceeded. The number and the area of roots measured in the different geological formations showed high variability (Tab. 5), but without a clear trend in the differences among the averages; number and area of roots significantly decreased with depth; while there were no significant differences among grapevine varieties, the type of soil management used by the vinegrower in the years had a significant effect on root development. The higher values of root number and area were found in the vineyard managed with cover grass and especially in the case of the alternation of cover grass with tillage between the rows. Conversely, total tillage of the vineyard soil decreased root development. The number of roots with diameters more than $2 \mathrm{~mm}$ and the area of these same roots tended to be higher in the case of the grass cover of the soil, but it is, of course, higher in the case of the method of alternate management in the rows, with values significantly higher also than total green cover. 
Table 5. Number (N r) and area (A r) of roots (see also the caption of Tab. 2).

\begin{tabular}{|c|c|c|c|c|}
\hline Var. & $\mathbf{N ~ r}$ & Area $\mathbf{r}$ & $\begin{array}{c}\mathrm{N} \mathrm{r} \\
>2 \mathrm{~mm}\end{array}$ & $\begin{array}{l}\text { Area } r \\
>2 \mathrm{~mm}\end{array}$ \\
\hline \multirow{4}{*}{$\begin{array}{cc}\text { Geo. } & L \\
F \\
b f\end{array}$} & $3.68^{*}$ & $10.97 * *$ & $9.42 * *$ & $9.45 * *$ \\
\hline & - & - & - & - \\
\hline & $0,96 n s$ & $3.99 * *$ & $3.09 *$ & $3.83 *$ \\
\hline & $\mathrm{n} . / \mathrm{m}^{2}$ & $\mathrm{~cm}^{2} / \mathrm{m}^{2}$ & $\mathrm{n} . / \mathrm{m}^{2}$ & $\mathrm{~cm}^{2} / \mathrm{m}^{2}$ \\
\hline Msaf & 183 & 11.24 & 70.37 & 9.28 \\
\hline Mmp & 234 & 12.35 & 84.26 & 10.25 \\
\hline FC & 188 & 8.08 & 62.50 & 6.56 \\
\hline VL & 206 & 14.07 & 133.33 & 16.87 \\
\hline \multirow[t]{4}{*}{ D. } & $10.31 * *$ & $14.6^{* *}$ & $4.97 * *$ & $0.22 n s$ \\
\hline & & & & $3.77^{*}$ \\
\hline & $96.0 * *$ & $41.4^{* *}$ & $1.87 n s$ & - \\
\hline & n. $/ \mathrm{m}^{2}$ & $\mathrm{~cm}^{2} / \mathrm{m}^{2}$ & $\mathrm{n} . / \mathrm{m}^{2}$ & $\mathrm{~cm}^{2} / \mathrm{m}^{2}$ \\
\hline $0-40$ & $302 \mathrm{c}$ & $18.52 \mathrm{c}$ & 22.23 & $11.39 \mathrm{~b}$ \\
\hline $41-80$ & $225 b$ & $13.34 \mathrm{~b}$ & 19.31 & $9.69 \mathrm{ab}$ \\
\hline $81-120$ & $74 a$ & $3.63 \mathrm{a}$ & 18.83 & $7.41 \mathrm{a}$ \\
\hline \multirow[t]{4}{*}{$c v$} & $3.41^{*}$ & $8.55 * *$ & $6.89 * *$ & $6.71 * *$ \\
\hline & - & - & - & - \\
\hline & $0.70 \mathrm{~ns}$ & $3.10^{*}$ & $3.11 n s$ & $3.09 n s$ \\
\hline & n. $/ \mathrm{m}^{2}$ & $\mathrm{~cm}^{2} / \mathrm{m}^{2}$ & $\mathrm{n} . / \mathrm{m}^{2}$ & $\mathrm{~cm}^{2} / \mathrm{m}^{2}$ \\
\hline PN & 179 & 9.20 & 73.84 & 8.62 \\
\hline CR & 209 & 14.18 & 80.99 & 10.81 \\
\hline RI & 204 & 9.94 & 67.13 & 7.99 \\
\hline ME & 217 & 15.12 & 198.15 & 24.63 \\
\hline \multirow{4}{*}{ M. $\begin{array}{l}L \\
F \\
\\
b f\end{array}$} & $5.79 * *$ & $9.61 * *$ & $15.40^{* *}$ & $15.76^{* *}$ \\
\hline & - & - & - & - \\
\hline & $5.14 * *$ & $5.06 * *$ & $3.78^{*}$ & $5.06^{* *}$ \\
\hline & $\mathrm{n} . / \mathrm{m}^{2}$ & $\mathrm{~cm}^{2} / \mathrm{m}^{2}$ & $\mathrm{n} . / \mathrm{m}^{2}$ & $\mathrm{~cm}^{2} / \mathrm{m}^{2}$ \\
\hline 1 & $146 a$ & $7.59 \mathrm{a}$ & $36.8 \mathrm{a}$ & $7.69 \mathrm{a}$ \\
\hline G & $204 b$ & $12.33 b$ & $95.7 \mathrm{ab}$ & $9.86 \mathrm{ab}$ \\
\hline GT & $229 b$ & $14.51 \mathrm{~b}$ & $148.5 b$ & $19.71 \mathrm{~b}$ \\
\hline
\end{tabular}

Calculating the correlation coefficients between the soil parameters evaluated and the measures of the roots, it is observed that the most significant positive correlations were, above all, with organic matter and $\mathrm{N}, \mathrm{P}$, and $\mathrm{K}$ whilst the correlations were negative with $\mathrm{pH}$ and $\mathrm{Mg}$ (Tab. 5, Fig. 2).

Tab. 5. Most significant correlation coefficients between Number ( $\mathrm{N} \mathrm{r}$ ), area (A r) of roots and the soil characteristics.

\begin{tabular}{|l|l|l|c|c|c|c|}
\hline & pH & $\mathbf{O . M .}$ & $\mathbf{N}$ & $\mathbf{P}$ & $\mathbf{K}$ & $\mathbf{M g}$ \\
\hline $\boldsymbol{N r}$ & 0.55 & 0.63 & 0.69 & 0.37 & 0.34 & -0.45 \\
$\boldsymbol{A r}$ & 0.50 & 0.68 & 0.68 & 0.42 & 0.42 & -0.25 \\
\hline
\end{tabular}

\section{Conclusion}

The soils of the Oltrepò Pavese area studied innortheastern Italy were found to be alkaline $(\mathrm{pH} 8.2-$ 8,3 ), fine textured, sometime calcareous, with a low level of organic matter $(<2.0 \%)$, but with high or too high level of $\mathrm{K}$ and $\mathrm{Mg}$, respectively. The use of grass mulching $(\mathrm{G})$ or its alternation with tillage between the adjacent rows (GT), has increased, over the years, the soil organic matter in comparison with tillage $(\mathrm{T})$ that frequently is associated with too low soil organic content $(<1.0 \%)$; however, the tillage of the vineyard rows after some years of green cover, has produced an increase of organic matter in the superficial layers of soil, in comparison with the total annual tillage. The size of the roots (number and area of their sections) is higher where green cover was permanently used $(\mathrm{G})$ or in alternation with tillage (GT). The roots showed significant positive correlations with the soil organic matter content and negative correlations with high $\mathrm{pH}$ and very high levels of $\mathrm{Mg}$.

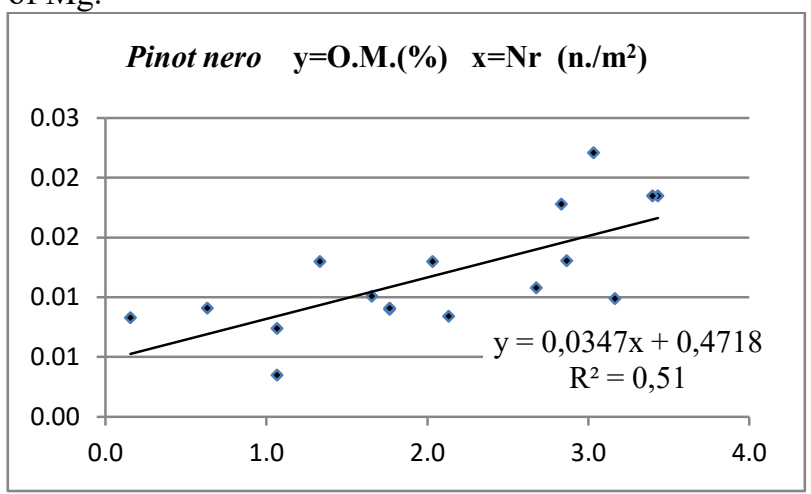

Fig. 2. Graphic representation of the linear regression between $\mathrm{Nr}$ (number of roots) and the soil organic matter content evaluated for the vines of Pinot nero.

\section{References}

1. E.W. Russell. Soil Conditions and Plant Growth ( Longman, London, 1973)

2. L. Tombesi, Elementi di scienza del suolo e di biologia vegetale. Guida all'interpretazione delle analisi dei terreni. (Edagricole, Bologna, 1977)

3. M. Bordoni, C. Meisina, A. Vercesi, G.B. Bischetti, E.A. Chiaradia, C. Vergani, Soil and Tillage Research, 163 (2016)

4. Saayman D.S. Afr. J. Enol. Vitic., 3 (1982)

5. Morlat R., Jacquet A., Vitis, 32 (1993)

6. R. Linares, M. de la Fuente, P. Junquera, J.R. Lissarrague, P. Baeza, Bio Web of Conferences, 3 (2014)

7. D. Powlson 1, P. Smith, M. De Nobili in Soil Conditions and Plant Growth, Peter J. Gregory and Stephen Nortcliff (Eds.) (Wiley-Blackwell, 2013)

8. A. Vercesi Proceedings VIII International Congress Terroir, Soave (VR) Italy, 1, (2010)

9. L. Pellegrini, P.L. Vercesi, I geositi della Provincia di Pavia (Ponzio and son, Pavia, 2005)

10. G.B. Bischetti, E.A. Chiaradia, T. Simonato, B. Speziali, B. Vitali, P. Vullo, A. Zocco, Plant Soil, 278 (2005)

11. M.B. Brown, A.B. Forsythe, Alan B., Journal of the American Statistical Association, 69 (1974). 